Rev. peru. biol. 7(2): 217-219 (2000)

(c) Facultad de Ciencias Biológicas UNMSM

ISSN 1561-0837

\title{
Recuerdos de un gran maestro
}

\author{
Por: Armando Yarlequé
}

E 11 de diciembre del año pasado falleció el Dr. Ernesto Melgar Salmón, profesor de Bioquímica de la Universidad de San Marcos y pionero en el país en las investigaciones sobre los ácidos nucleicos, el material genético de los seres vivos. Su repentino fallecimiento ha dejado una estela de pesar en la comunidad científica peruana y nos ha llamado a una profunda reflexión sobre la obra de este gran maestro universitario, quien desde muy joven cosechó los éxitos de su trabajo profesional y también se enfrentó a los innumerables problemas que como seres humanos nos toca vivir en un mundo lleno de conflictos y cambios inesperados. Haber conocido muy de cerca al Dr. Melgar me permite reseñar algunos aspectos del temperamento, la personalidad y los conocimientos de este singular científico cuyo modelo he tratado de seguir.

Corría al año de 1969 y el gobierno de facto del general Velasco había cambiado la estructura académica de las universidades. Las Facultades habían desaparecido y en su lugar se crearon los Programas Académicos, que eran en buena cuenta las carreras profesionales y los Departamentos Académicos, en los que se agrupaban los profesores de disciplinas afines. Fue esta coyuntura que determinó que el curso de Bioquímica para la promoción "Octavio Velarde 1970", a la que pertenezco, lo organizara el Departamento de Bioquímica y Fisiología cuyo jefe era el Dr. Marino Villavicencio, actualmente radicado en Brasil. Debo reconocer que mis dotes memorísticas se habían doblegado frente a la abundancia y prolijidad de los datos taxonómicos recibidos en los cursos previos y, como siempre ocurre en nuestra época de estudiante, ese curso fue el punto inicial de mi vida profesional. Recuerdo que la jefe del curso era la Dra. Rosa Vásquez y entre los participantes destacaba el profesor Orestes Málaga, actual Director de Asuntos Académicos de nuestra Facultad. El Dr. Melgar nos dictó el capítulo sobre ácidos nucleicos, y habiendo regresado hacía pocos meses de la Western Reserve University de Cleveland, Ohio en USA, donde trabajó sobre el tema, sus conocimientos acerca de la estructura del DNA eran frescos y abundantes; además poseía una didáctica que impresionó a todos en general y a mí en particular. En esa época los estudios sobre la clave genética estaban en plena ejecución a raíz de los trabajos de James Watson y Frances Crick, ganadores del premio Nobel en 1962 al elucidar la estructura secundaria del DNA.

El Dr. Melgar era un profesor muy peculiar, pues su voz potente y emotiva contrastaba con espacios de absoluto silencio que a nosotros nos permitía captar y analizar lo dicho por él. Se paseaba por el salón de clase, movía las manos con mucha energía, 
gesticulaba y hacía bromas dè las que él mismo disfrutaba con una risa estentórea y prolongada. A veces nos contaba breves aspectos de su asistencia a reuniones internacionales, como el curso sobre energía atómica en la India o la azarosa reunión en Israel que coincidió con la llamada "Guerra de los Seis Días", que enfrentó a ese país con Egipto y en la que involuntariamente se vieron involucrados los científicos que asistieron a dicho evento. Allí nació mi amistad con él y mis visitas cada vez más frecuentes al Instituto de Bioquímica y Nutrición que funciona en la Facultad de Medicina donde admiré las facilidades del laboratorio y de equipos que tenían a su disposición los investigadores de ese Instituto. El Dr. Melgar me recibía muy cordialmente, pero muchas veces en plena conversación salía presuroso de su oficina para atender experimentos indescifrables para mí y que se ejecutaban en el laboratorio. Siendo un Instituto en realidad muy selectivo, pues trabajaban profesionales de gran calificación, sabía que mis posibilidades de hacer mi tesis de bachiller en ese lugar eran mínimas, pero cierto momento tomé la decisión y le pedí que me diera esa oportunidad. Se quedó pensando varios segundos y finalmente me dijo que leyera mucho sobre el tema de las enzimas nucleolíticas y que esperásemos a la Dra. Beatriz Lizárraga, quien estaba en Chile.

En este momento quiero detenerme brevemente para hacer una reflexión importante, ahora que estamos en una recuperación plena del trabajo universitario de acuerdo con la ley que establece la participación estudiantil en los órganos de gobierno de la Universidad. En algunas ocasiones se cometieron excesos lamentables, utilizando la buena fe del estudiante y sus escasos conocimientos de las calificaciones personales y profesionales de sus profesores. Digo esto porque nosotros, como promoción, habíamos recibido información negativa sobre la Dr. Lizárraga y que a raíz de la conversación con el Dr. Melgar me hizo temer las dificultades que tendría para hacer mi tesis; no sabíamos, por ejemplo que la Dra. Lizárraga había realizado sus estudios de Maestría en la Universidad de Indiana, nada menos que en la misma universidad de Salvador Luria y James Watson, dos de los más grandes científicos del mundo y que después de ello viajó a Chile para realizar un post-grado en el laboratorio del Dr. Carlos Basilio; por ello los datos que a veces uno recibe como estudiante de personas simplemente dedicadas al quehacer político y no al académico pueden causar confusiones como la que estoy señalando. Como sabemos, la Dra. Lizárraga es actualmente, con todo merecimiento, la Vicerrectora Académica de la Universidad.

Un día de los tantos que fui al Instituto en busca de información bibliográfica y tratando de que algún profesor me ayudase a traducir un artículo, conocí a una profesora que no sólo me prestó su ayuda sino que me invitó a seguir visitándola para cualquier duda que tuviera. Su actitud jovial, afectuosa e interesada en apoyarme me hizo preguntarle, después de varias visitas, cómo se llamaba; era la Dra. Lizárraga.

Lo que continuó fue un aprendizaje sucesivo y vertiginoso al lado de un científico admirable como el Dr. Melgar, médico de profesión pero biólogo de corazón, quien era muy rápido para explicar y diseñar experimentos y muy exigente para evaluar los resultados del trabajo. Las muchas dudas que me quedaban mientras trabajaba eran disipadas a veces con lentitud por el análisis que hacía de toda la información recibida y en otros casos por la maternal y comprensiva actitud de la doctora Lizárraga, quien me explicaba en forma prolija detalles que no alcanzaba a entender. El Dr. Melgar leía mucho y trabajaba muchas horas al día, era un hombre muy sencillo, con amplia cultura, muy locuaz y enérgico en sus convicciones, pero también era muy peculiar, pues a veces se tornaba taciturno y alejado de lo que lo rodeaba; en esos momentos era preferible no hablarle porque a pesar de estar fren- 
te a uno simplemente no escuchaba. Siempre admiré su elocuencia y facilidad para escribir en especial artículos científicos en inglés, idioma que en ese entonces me era muy lejano. $\mathrm{Su}$ habilidad para actuar como intérprete en las numerosas conferencias que se dictaban en el Instituto era impresionante no sólo por su gran capacidad de retener lo que decía el expositor, sino porque le añadía su propia explicación ampliatoria para mejor entendimiento del oyente. Aprendí de él a valorar el esfuerzo y el trabajo del estudiante y del que se inicia en el campo de la investigación; también aprendía a publicar la información respetando escrupulosamente al autor, es decir, a quien estaba efectuando el trabajo; así mismo fui entendiendo cómo preparar cuidadosamente los diversos ensayos experimentales, a buscar las soluciones cuando falta un equipo o un material determinado usando como herramientas el ingenio y el conocimiento. La presentación de los trabajos en congresos se realizaba previos ensayos en los que, como expositores novatos, éramos sometidos al duro procedimiento de recibir una andanada de preguntas y críticas tendientes a corregir nuestros numerosos defectos, y repetíamos la exposición hasta tener la conformidad de los asistentes.

Toda esta vasta experiencia adquirida en base a un formidable modelo científico indudablemente nos sirvió a todos quienès tuvimos la oportunidad y la suerte de aprender del Dr. Melgar. Un ejemplo de este exitoso modo de enseñanza lo tenemos en el Dr. Carlos Bustamante, recientemente nominado profesor honorario de la Universidad, un científico de muy alta calificación y que actualmente es profesor de la Universidad de Oregon; tal vez el Dr. Bustamante sea el representante más notable de la escuela establecida por el Dr. Melgar.
En sus 64 años de vida, el Dr. Melgar ocupó numerosos cargos académicos y administrativos, y fue uno de los profesores que propició el actual esquema de las orientaciones en esta Facultad; también impulso vigorosamente la creación de las Maestrías en Bioquímica, que se iniciaron en 1971. Fue Vicerrector Académico de la Universidad Nacional Mayor de San Marcos desde 1985 y alcanzó el Rectorado en 1986; también fue un destacado miembro del Consejo Nacional de Investigaciones (ahora CONCYTEC) y realizó numerosos viajes al extranjero para exponer sus investigaciones o en representación oficial de instituciones del país; fue también un incansable impulsor de la División Bioquímica de la Sociedad Química del Perú, y su gran experiencia le valió, en los últimos años, ser integrante de la Comisión Reorganizadora de la Universidad Nacional Federico Villarreal. Siempre fue un hombre muy crítico, buscador de la excelencia académica, respetuoso de los valores docentes y científicos de sus colegas, muy poco dado a los elogios; sólo en junio del 2000, actuando como presentador de mi libro Las Serpientes Peruanas y sus Venenos, dijo palabras halagadoras y reconfortantes alusivas a mi trabajo de tesista, las que me impresionaron no sólo por tratarse de una persona de su calidad, sino por los casi 30 años transcurridos desde esa época. Me siento orgulloso de haber sido su discípulo y me esfuerzo cada día en usar sus enseñanzas, talento y habilidades científicas.

¡Descanse en paz, Dr. Melgar, porque todos los que fuimos parte de su escuela seguimos trabajando para engrandecer su nombre y perennizar su imagen! 